\title{
NASKAH AKADEMIK RANCANGAN PERATURAN DAERAH TENTANG TATA CARA PENCALONAN, PEMILIHAN, PENGANGKATAN, PELANTIKAN DAN PEMBERHENTIAN KEPALA DESA
}

M Chairul Basrun Umanailo ${ }^{1}$, Annisa Retrofilia Umanailo ${ }^{1}$, and Askar Daffa Sophia Umanailo $^{1}$

${ }^{1}$ Affiliation not available

December 21, 2020

\section{Hosted file}

NASKAH AKADEMIK TATA CARA PENCALONAN, PEMILIHAN, PENGANGKATAN, PELANTIKAN DAN PEMBERHENTIAN KEPALA DESA available at https://authorea.com/users/310886/articles/498959-naskah-akademik-rancanganperaturan-daerah-tentang-tata-cara-pencalonan-pemilihan-pengangkatan-pelantikan-danpemberhentian-kepala-desa 